DOI: 10.17707/AgricultForest.62.1.01

\author{
Gordan S. KARAMAN ${ }^{1}$
}

\title{
TWO NEW GENERA OF THE FAMILY NIPHARGIDAE FROM GREECE (CONTRIBUTION TO THE KNOWLEDGE OF THE AMPHIPODA 287)
}

\begin{abstract}
From the subterranean waters of Tzanis spilios Cave, Lefka Ori Massif, W. part of Crete Island, Greece, a new genus and species of the family Niphargidae (Crustacea, Amphipoda) is described and figured, Exniphargus tzanisi, gen. nov., sp. n., and its relationship to other genera of the family Niphargidae is discussed.

The species Niphargobates lefkodemonaki Sket, 1990, known from Crete Island. Greece, is removed to the new genus Niphargobatoides, gen. nov. as typus generis (type species); differences and relationship of this genus regarding other genera are presented. New diagnosis of the genus Niphargobates Sket, 1981 is given and the key to the genera of the family Niphargidae is composed.

Keywords: Amphipoda, Niphargidae, new genera, new species, key to the genera, Greece.
\end{abstract}

\section{INTRODUCTION}

The dominant subterranean amphipods (Crustacea, Amphipoda) in the subterranean waters of Europe and Near East are the members of the family Niphargidae, replaced in North America by the family Crangonyctidae, especially genus Stygobromus Cope, 1872: 422 (T. sp.: Stygobromus vitreus Cope, 1872) (G. Karaman, 1974). The family Niphargidae is presented in Europe by 12 known genera:

Carinurella Sket, 1971 [Type sp.: Carinurella paradoxa (Sket, 1964)];

Exniphargus, gen. nov. [Type sp.: Exniphargus tzanisi sp. n.];

Foroniphargus G. Karaman, 1985 [Type sp.: Foroniphargus pori G. Karaman, 1985];

Haploginglymus Mateus \& Mateus, 1958 [Type sp.: Haploginglymus bragai Mateus \& Mateus, 1958];

Karamaniella Sket, 1962 [Type sp.: Karamaniella pupetta Sket, 1962];

Microniphargus Schellenberg, 1934 [Type sp.: Microniphargus leruthi, Schellenberg, 1934];

Niphargellus Schellenberg, 1938 [Type sp.: Niphargus arndti, Schellenberg, 1933]; 1981];

Niphargobates Sket, 1981 [Type sp.: Niphargobates orophobata Sket,

\footnotetext{
${ }^{1}$ Gordan S. Karaman (corresponding author: karaman@t-com.me) Montenegrin Academy of Sciences and Arts, Podgorica, Montenegro

Note: The authors declare that they have no conflicts of interest. Authorship Form signed online.
} 
Niphargobatoides gen. nov. [Type sp.: Niphargobates lefkodemonaki (Sket, 1990)];

Niphargopsis Chevreux, 1922 [Type sp.: Niphargopsis casparyi (Pratz, 1866)];

Niphargus Schiödte, 1849 [Type sp.: Niphargus stygius (Schiǒdte, 1847)];

Pontoniphargus Dancau, 1970 [Type sp.: Pontoniphargus racovitzai, Dancau, 1970].

Among them, genus Niphargus is the most numerous, with over 200 known taxa divided into various subgenera often not clearly divided to each other.

During our recent study of the family Niphargidae from Greece, we discovered a new species belonging to the new genus Exniphargus, gen. nov., based on some specific characters of its mouthparts (maxilla 1, maxilliped, etc.) and combination of other morphological characters. On the other hands, based on the morphological analysis of genera of the family Niphargidae, the species Niphargobates lefkodemonaki Sket, 1990 is removed to the new genus Niphargobatoides, gen. nov. as a typus generis.

\section{MATERIAL AND METHODS}

The collected material was preserved in the $70 \%$ ethanol. The specimens were dissected using a WILD M20 microscope and drawn using camera lucida attachment. All appendages were temporarily submersed in the mixture of glycerine and water for study and drawing. Later, all appendages have been transferred to Liquid of Faure on permanent slides. The body-length of examined specimens were measured by tracing individual's mid-trunk lengths (from tip of head to end of telson) using camera lucida. All illustrations were inked manually.

Some morphological terminology and setae formulae follow G. Karaman's terminology (Karaman, G., 1969; 1993; 2012a) regarding the last mandibular palpus article $[\mathrm{A}=$ setae on outer face; $\mathrm{B}=$ setae on inner face; $\mathrm{C}=$ additional setae on outer face; $\mathrm{D}=$ lateral marginal setae; $\mathrm{E}=$ distal long setae] and propodus of gnathopods 1 and 2 [ $S=$ corner spine; $L=$ lateral slender serrate spines; $M=$ facial setae; $\mathrm{R}=$ subcorner spine on inner face]. Terms "setae" and "spines" are used based on its shape, not origin.

All studies in this work are based on the classic morphological, ecological and zoogeographical studies.

\section{TAXONOMICAL PART \\ Family NIPHARGIDAE}

Genus EXNIPHARGUS gen. nov.

DIAGNOSIS of the genus:

Eyes absent; body and telson Niphargus-like. Antenna 1 with 2articulated accessory flagellum; antennal gland cone short.

Mouthparts: labrum entire; labium with small inner lobes; mandibles with triturative molar; right mandible: molar with long lateral seta, incisor with 5 
teeth, and lacinia mobilis with 4 teeth, accompanied by several rakers. Left mandible: incisor with 4 teeth, lacinia mobilis with several teeth, accompanied by several rakers; mandible palpus 3-articulated, last article subfalciform, with A, B, D and E-setae. Maxilla 1: inner plate well developed, with distal setae, outer plate broad, with numerous pectinate spines, palpus 2-articulated, well developed. Maxilla 2 outer plate slightly larger than inner one, both plates with marginal setae only. Maxilliped: inner and outer plate well developed but relatively short, palpus article 4 with 3 distal nails (spines) and single short setae.

Coxae relatively short, coxa 4 without distinct posterior lobe, coxa 5 much shorter than 4; gnathopods 1-2 Niphargus-like. Pereopods 5-7 with dilated article 2. Pleopods and uropods 1-2 biramous, Niphargus-like. Uropod 3: inner ramus short, scale-like, outer ramus elongated, 2-articulated, Niphargus-like. Telson Niphargus-like. Sexual dimorphic characters scarce. Coxal gills occur on the corresponding legs 2-6, oostegites occur on the corresponding legs 2-5.

TYPUS GENERIS: Exniphargus tzanisi, sp. n.

TAXA: Only type species is known.

DISTRIBUTION: Crete Island, Greece.

DERIVATIO NOMINIS: The name Exniphargus alluding to Latin words "former Niphargus".

EXNIPHARGUS TZANISI, sp. n.

Figs. 1-8

\section{MATERIAL EXAMINED:}

Greece: Tzanis spilios Cave, Lefka Ori Massif, W. part of Crete Island, September, 1988, 5 exp. (leg. B. Sket).

\section{DIAGNOSIS}

Body Niphargus-like, eyes absent, accessory flagellum of antenna 1 consisting of 2 articles. Labium with small inner lobes. Mandible Niphargus-like, palpus well developed, 3-articulate. Maxilla 2 inner plate slightly smaller than outer plate, both plates with distal setae. Maxilla 1 inner plate narrowed, outer plate broad, with 14 slender pectinate spines, palpus 2-articulated, well developed. Maxilliped inner and outer plate well developed, palpus article 4 with 3 distal nails (spines). Coxa 5 shorter than coxa 4. Gnathopods 1-2 and pereopods 3-7 Niphargus-like. Uropods 1-2 biramous. Uropod 3 biramous, inner ramus consisting of one article, scale-like, outer ramus 2-articulate, second article short. Telson incised.

\section{DESCRIPTION. Male 8.5 mm.}

Body moderately slender, Niphargus-like, mesosomal segments naked; metasomal segments 1-3 with 3-4 dorsoposterior marginal setae (fig. 2G). Urosomal segment 1 on each dorsolateral side with 1 seta (fig. $4 \mathrm{H}$ ); urosomal segment 2 on each dorsolateral side with one spine and one seta; urosomal segment 3 naked. Urosomal segment 1 in both ventroposterior corners with one spine near basis of the uropod 1 peduncle (fig. $4 \mathrm{H}$ ). 


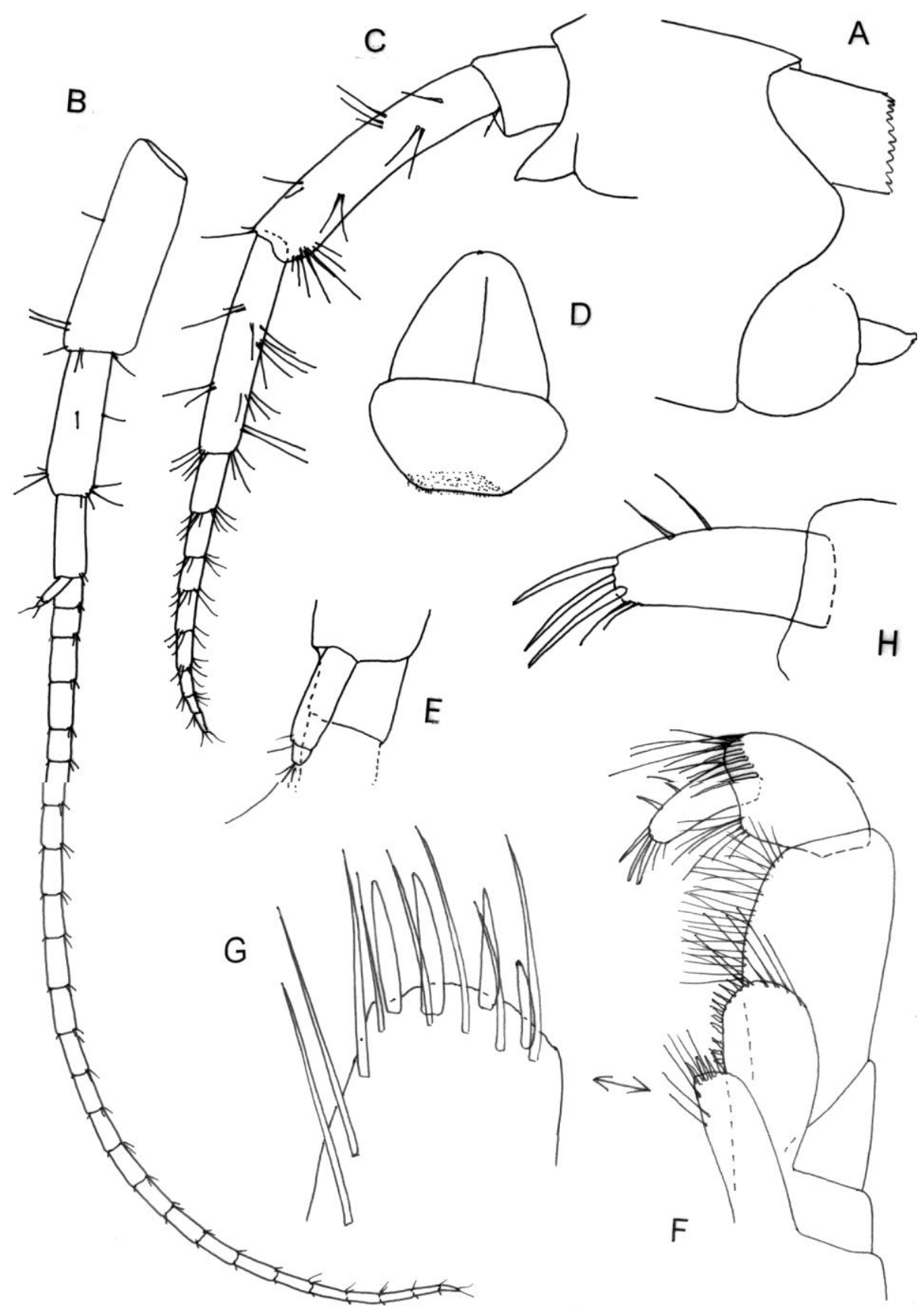

Figure 1. Exniphargus tzanisi, gen. n. sp. n., Tzanis spilios, Crete Island, male $8.5 \mathrm{~mm}$ (holotype): $\mathrm{A}=$ head; $\mathrm{B}=$ antenna $1 ; \mathrm{C}=$ antenna $2 ; \mathrm{D}=$ labrum; $\mathrm{E}=$ accessory flagellum; $\mathrm{F}=$ maxilliped; $\mathrm{G}=$ inner plate of maxilliped; $\mathrm{H}=$ palpus article 4 of maxilliped. 


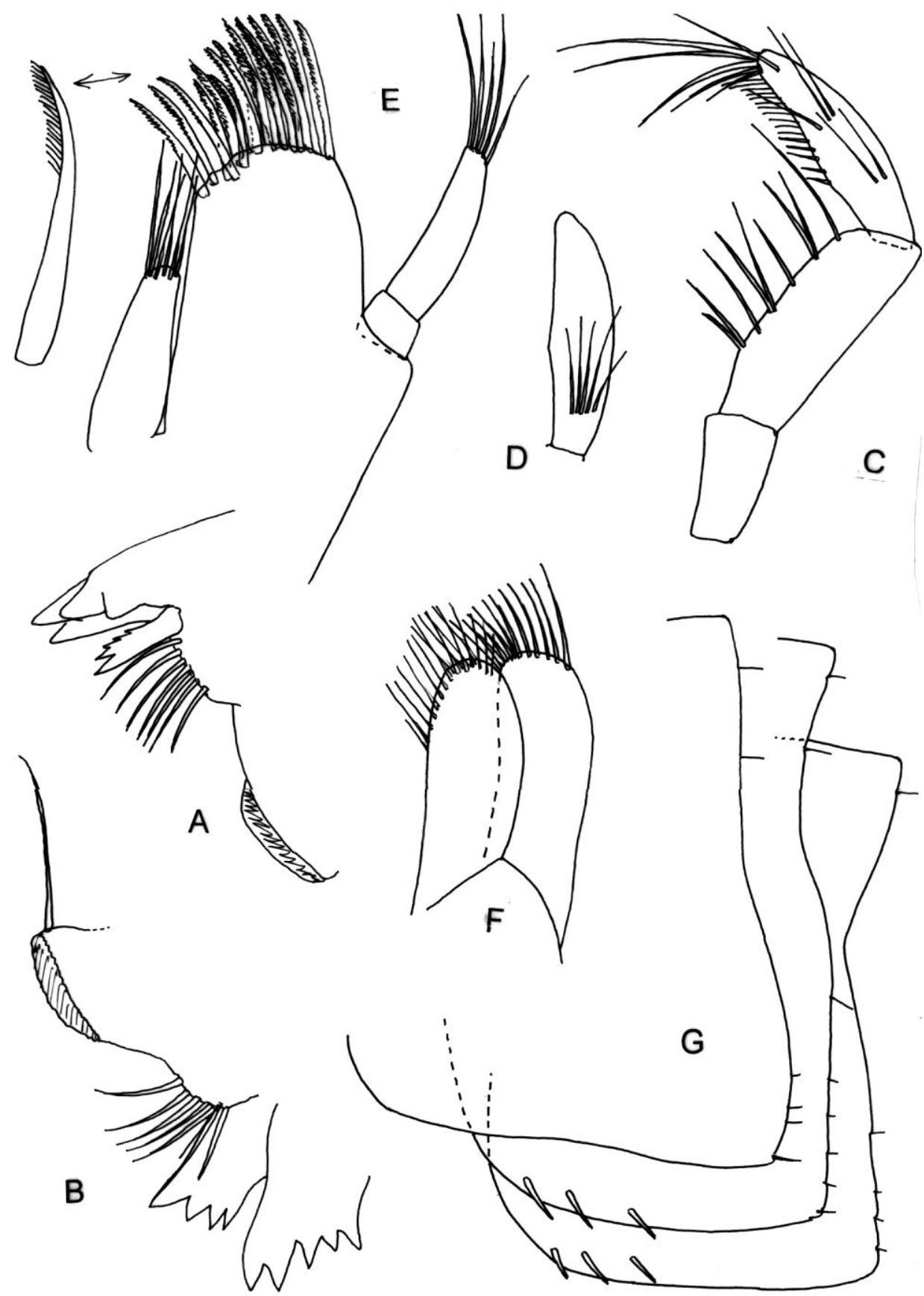

Figure 2. Exniphargus tzanisi, gen. n. sp. n., Tzanis spilios, Crete Island, male $8.5 \mathrm{~mm}$ (holotype): $\mathrm{A}=$ left incisor and lacinia mobilis; $\mathrm{B}=$ right incisor and lacinia mobilis; $\mathrm{C}=$ mandible palpus, inner face; $\mathrm{D}=$ distal mandible palpus article, outer face; $\mathrm{E}=$ maxilla $1 ; \mathrm{F}=$ maxilla $2 ; \mathrm{G}=$ epimeral plates $1-3$. 
Epimeral plates strongly angular. Epimeral plate 1 with distinctly marked ventroposterior corner by 1 slender spine, along posterior moderately convex margin with 3 short setae, ventral margin poorly concave in the middle. Epimeral plate 2 with marked ventroposterior corner by 1 spine-like seta, posterior distal margin straight, bearing 5-6 short setae. Epimeral plate 3 with angular ventroposterior corner, along posterior straight and poorly inclined margin appear 4 short setae; epimeral plates 2 and 3 with 3 subventral spines each (fig. 2G). Sexual papillae are attached at ventral margin of metasomal segment 3 (fig. 6B).

Head with short rostrum and short subrounded lateral cephalic lobes and concave ventroanterior excavation (fig. 1A), eyes absent.

Antenna 1 almost reaching the half of body-length (ratio: 85:40). Peduncle moderately slender, scarcely setose, peduncular articles progressively shorter (ratio: 58:39:22) (fig. 1B); main flagellum slender, consisting of 25 scarcely setose articles (most of them with one short aesthetasc). Accessory flagellum much shorter than last peduncular article and consisting of 2 unequal articles bearing distal setae (fig. 1E).

Antenna 2 shorter than antenna 1, peduncle moderately slender, peduncular article 3 short, nearly as long a broad (fig. 1C); peduncular article 4 slightly longer than article 5 (ratio: 70:59), along ventral margin with 3 bunches of short setae (fig. 1C), along dorsal margin with 3 groups of 2-3 setae each; peduncular article 5 at ventral margin with 4 bunches of setae (the longest setae exceeding the diameter of article itself), along dorsal margin with 3 groups of several setae each. Flagellum longer than last peduncular article (ratio: 74:59), consisting of 8 articles; antennal gland cone short (fig. 1C).

MOUTHPARTS. Labrum twice broader than long (fig. 1D). Labium broader than long, inner lobes short, outer lobes broad, entire, convex distally (fig. 3A).

Mandible well developed. Right mandible with triturative molar bearing long lateral seta (fig. 2B), incisor with 5 teeth, lacinia mobilis with 4 teeth accompanied by 7 rakers (fig. 2B). Left mandible: triturative molar without long lateral seta, incisor with 4 teeth, lacinia mobilis with several teeth accompanied by 7 rakers (fig. 2A). Palpus of left and right mandible symmetric: first article short, naked (fig. 2C); second article with 9 lateral setae; third article poorly shorter than second article (ratio: 60:64), subfalciform, bearing nearly $16 \mathrm{D}$-setae and 5 E-setae (fig. 2C), on outer face appear one row of 5 A-setae (fig. 2D), on inner face are attached 3 groups of B-setae (2-3-1) (fig. 2C).

Maxilla 1: inner plate narrowed, with 6 distal setae (fig. 2E), outer plate with 14 densely pectinate slender spines (fig. 2E); palpus 2-articulated, poorly exceeding basis of outer plate spines and provided with 5 distal setae (fig. 2E).

Maxilla 2: outer plate slightly larger than inner one, bearing distal setae only (fig. 2F); inner plate with distolateral setae (fig. 2F). 


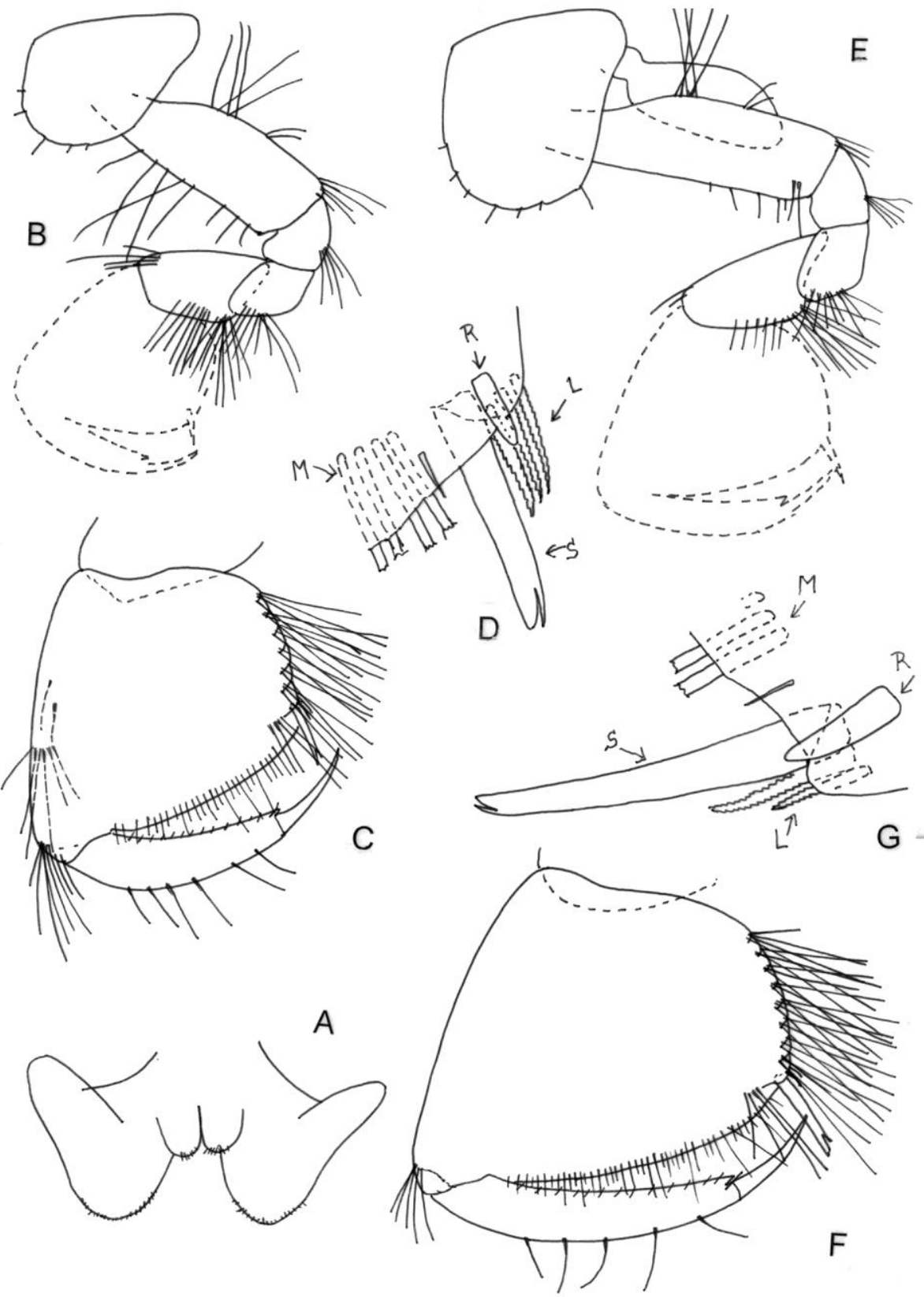

Figure 3. Exniphargus tzanisi, gen. n. sp. n., Tzanis spilios, Crete Island, male $8.5 \mathrm{~mm}$ (holotype): $\mathrm{A}=$ labium; $\mathrm{B}-\mathrm{C}=$ gnathopod 1 , outer face; $\mathrm{D}=$ distal corner of gnathopod 1 propodus, inner face $[\mathrm{S}=$ corner spine; $\mathrm{L}=$ lateral spines; $\mathrm{R}=$ subcorner spine; $\mathrm{M}=$ facial $\mathrm{M}$-setae]; $\mathrm{E}-\mathrm{F}=$ gnathopod 2, outer face; $\mathrm{G}=$ distal corner of gnathopod 2 propodus, inner face $[\mathrm{S}=$ corner spine; $\mathrm{L}=$ lateral spines; $\mathrm{R}=$ subcorner spine; $\mathrm{M}=$ facial $\mathrm{M}$-setae]. 
Maxilliped: inner plate reaching outer tip of palpus article 1, bearing 3-4 distal pointed spines intermixed with single setae longer than spines, as well as with 3 lateral setae at inner margin (fig. 1G); outer plate short, not exceeding half of palpus article 2, with row of pointed distointernal marginal spines and several distal long setae; palpus article 2 at inner margin with numerous setae (fig. 1F); palpus article 3 at inner margin with bunch of setae, at distoexternal margin with row of setae and spine-like setae (fig. 1F). Palpus article 4 with 3 distal strong nails (spines) (equivalent to nail in Niphargus taxa) accompanied by 2 slender setae (fig. 1H), at outer margin with 1-2 strong median setae.

Coxae relatively short. Coxa 1 broader than long (ratio: 45:33), with subrounded ventroanterior corner and provided with 5 marginal setae (fig. 3B). Coxa 2 as long as broad, with convex ventral margin bearing 7 marginal setae (fig. 3E). Coxa 3 slightly longer than broad (ratio: 58:46), at ventral convex margin with 6 setae (fig. 4A). Coxa 4 slightly longer than broad (ratio: 62:50), with convex ventral margin and without distinct ventroposterior lobe, bearing 7 marginal setae (fig. 4C).

Coxa 5 much shorter than coxa 4, broader than long (ratio: 60:35), anterior subrounded lobe only poorly longer than posterior lobe (fig. 5A).

Coxa 6 similar to coxa 5 but smaller, broader than long (ratio: 51:30), with convex anterior lobe poorly longer than posterior one (fig. 5C).

Coxa 7 much broader than long (ratio: 56:22), with convex ventral margin (fig. 5F).

Propodus of gnathopod 1 and gnathopod 2 are remarkably larger than corresponding coxa. Gnathopod 1: article 2 along anterior margin with row of long setae (setae in proximal part are longer than these in distal part), along posterior margin with median and distal bunch of long setae; article 3 at posterior margin with one bunch of setae (fig. 3B); article 5 shorter than article 6 (propodus) (ratio: 32:47), along anterior margin with distal bunch of setae (fig. 3B). Propodus trapezoid, hardly longer than broad (ratio: 72:69), along posterior margin with 6 transverse rows of setae (fig. 3C). Palm poorly convex, inclined over half of propodus length, defined on outer face by one corner S-spine accompanied laterally by 3 slender serrate L-spines and facial 4 long M-setae (fig. 3D), on inner face by one short subcorner R-spine (fig. 3D). Dactylus reaching posterior margin of propodus, along outer margin with 6 single median setae, along inner margin with row of numerous short setae (fig. 3C).

Gnathopod 2 is slightly larger than gnathopod 1; article 2 along anterior margin with row of short setae in distal part, no setae in proximal part of article; along posterior margin of article 2 appears one proximal bunch of long setae and one median pair of short setae, as well as distal bunch of shorter setae. Article 3 at posterior margin with one bunch of setae (fig. 3E); article 5 shorter than article 6 (propodus) (ratio: 40:50), at anterior margin with distal bunch of setae. Propodus nearly as long as broad, along posterior margin with 8 transverse rows of setae (fig. $3 \mathrm{~F}$ ); palm slightly convex and inclined almost $2 / 3$ of propoduslength, defined on outer face by one corner S-spine accompanied laterally by $2 \mathrm{~L}$ spines and 4 long M-setae, on inner face by one subcorner R-spine (fig. 3G). Dactylus reaching posterior margin of propodus, bearing 5 median single setae along outer margin and numerous short setae at inner margin (fig. 3F). 


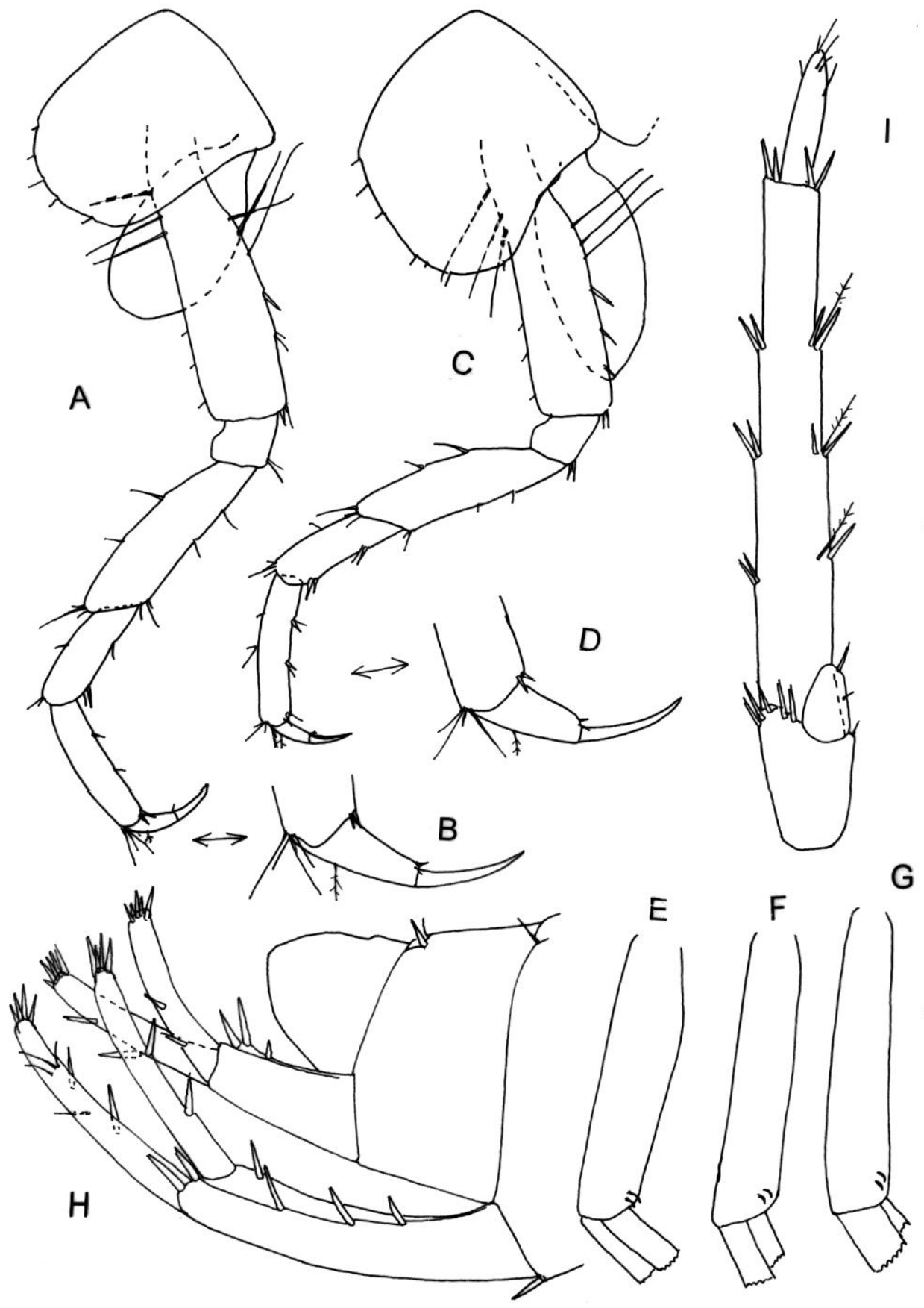

Figure 4. Exniphargus tzanisi, gen. n. sp. n., Tzanis spilios, Crete Island, male $8.5 \mathrm{~mm}$ (holotype): A-B= pereopod 3; $\mathrm{C}-\mathrm{D}=$ pereopod $4 ; \mathrm{E}-\mathrm{F}-\mathrm{G}=$ peduncle of pleopods $1-3 ; \mathrm{H}=$ urosome with uropods $1-2 ; \mathrm{I}=$ uropod 3 . 
Pereopods 3 and 4 similar to each other. Pereopod 3: article 2 with several long proximal setae at anterior and posterior margin, and 3-4 short setae in distal part of anterior margin; one median spine and pair of short setae are attached at posterior margin and tip. Articles 4-6 are of different length (ratio: 50:29:37), scarcely setose (fig. 4A), single setae and spines are shorter than diameter of articles themselves. Dactylus moderately strong and elongated, shorter than article 6 (ratio: 24:37), along inner margin with one spine-like seta near basis of the nail, along outer margin with one median plumose seta (fig. 4B), nail rather shorter than pedestal (ratio: 28:35).

Pereopod 4: posterior margin of article 2 with 3 proximal long setae and 4-5 short spines, along anterior margin provided with 3 long proximal setae and 3 short setae in distal part (fig. 4C); articles 4-6 of different length (ratio: 47:32:39); articles 5 and 6 at posterior margin with bunches of short spines and single setae; dactylus rather elongated, shorter than article 6 (ratio: 23:38), at inner margin with one spine-like seta or slender spine near basis of the nail, along outer margin with one median seta (fig. 4D); nail shorter than pedestal (ratio: 28:30).

Pereopod 5 is remarkably shorter than pereopods 6 and 7 (fig. 5A, C, F). Pereopod 5: article 2 longer than broad (ratio: 73:46), along anterior convex margin with row of 6 slender spines, along posterior slightly convex margin with 13 short setae, ventroposterior lobe not developed (fig. 5A). Articles 4-6 of unequal length (ratio: 48:60:65), along both margins with short spines and setae not exceeding the diameter of articles themselves (fig. 5A); article 2 is longer than article 6 (ratio: 73:65). Dactylus shorter than article 6 (ratio: 28:65), at inner margin with one short spine-like seta and one short seta near basis of the nail, along outer margin with one median plumose seta (fig. 5B); nail shorter than pedestal (ratio: 29:37).

Pereopod 6: article 2 longer than broad (ratio: 85:51), along anterior margin with row of short spines, along posterior margin with 12 short setae, ventroposterior lobe not developed (fig. 5C). Articles 4-6 of different length (ratio: 56:80:100), along both margins with bunches of short spines and single setae not exceeding the width of articles themselves (fig. 5D). Article 2 is shorter than article 6 (ratio: 85:100). Dactylus shorter than article 6 (ratio: 34:100), at inner margin with short spine-like seta and short seta near basis of the nail (fig. $5 \mathrm{E}$ ), along outer margin with one median plumose seta; nail is shorter than pedestal (ratio: 30:50).

Pereopod 7: article 2 longer than broad (ratio: 87:51), along anterior margin with row of 6 pairs of single short slender spines, along posterior margin with 12 short setae, ventroposterior lobe not fully developed (fig. 5F); articles 4-6 of unequal length (ratio: 53:77:100), along both margins with bunches or single short spines not exceeding diameter of articles themselves (fig. 5G). Article 2 is shorter than article 6 (ratio: 87:100). Dactylus is much shorter than article 6 (ratio: 33:100), at inner margin with short small spine and seta near basis of the nail (fig. $5 \mathrm{H}$ ), along outer margin with one median plumose seta; nail shorter than pedestal (ratio: $31: 50$ ). 


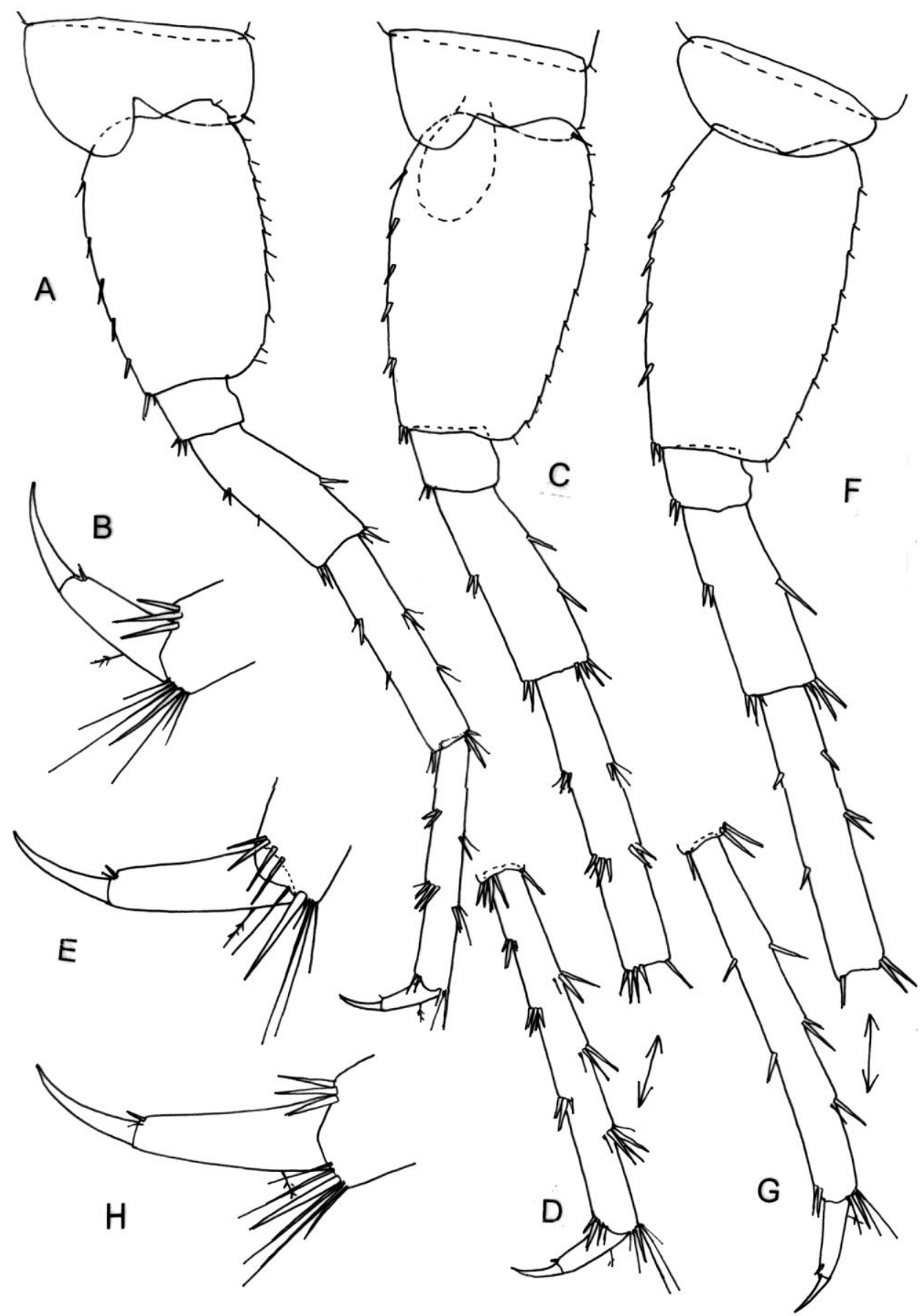

Figure 5. Exniphargus tzanisi, gen. n. sp. n., Tzanis spilios, Crete Island, male $8.5 \mathrm{~mm}$ (holotype): A-B= pereopod 5; C-D-E= pereopod 6; F-G-H= pereopod 7 . 
4E, F, G).

Pleopods 1-3 with 2 retinacula each, peduncle of all pleopods naked (fig.

Uropod 1: peduncle longer than rami, with dorsoexternal row of strong spines, on dorsointernal margin appears only distal spine (fig. 4H); inner ramus scarcely longer than outer one, bearing 2 median strong spines at lateral margin and 4 distal short spines (fig. $4 \mathrm{H}$ ); outer margin with 2 lateral median single strong spines and 2 bunches of 1-3 short setae, as well as with 4 distal short spines (fig. 4H).

Uropod 2: outer ramus scarcely twisted (in lateral projection), bearing 2 lateral single spines and 5 distal short spines; inner ramus scarcely longer than outer one, or almost equally long, bearing 2 lateral single strong spines and 5 distal short spines (fig. $4 \mathrm{H}$ ).

Uropod 3 moderately long: peduncle less than twice as long as broad, with several distal spines; inner ramus consists of one article, short, scale-like, shorter than peduncle and bearing one lateral seta and one distal spine (fig. $4 \mathrm{I}$ ); outer ramus 2-articulated: first article along outer margin with 4 bunches of short strong spines, along inner margin with 4 bunches of spines accompanied by single plumose setae longer than spines themselves (fig. 4 I); second article much shorter than first article (ratio: 35:145), bearing several distolateral simple setae (fig. 4 I).

Telson slightly longer than broad (ratio: 81:70), incised over $2 / 3$ of telson-length, slightly gapping, lobes slightly tapering distally and bearing 3 short distal spines each (fig. 6A); a pair of unequal plumose setae appears on each lobe in upper half of its outer margin.

Coxal gills ovoid, relatively short, never reaching ventral margin of corresponding article 2 of the legs 2-6 (figs. 3E, 4A, C; 5C).

Left and right genital palpus on ventral median surface on metasomal segment 3 is well developed.

FEMALE $8.1 \mathrm{~mm}$ with setose oostegites:

Body is similar to male. Metasomal segments 1-3 with 4 dorsoposterior marginal short setae each. Urosomal segment 1 on each dorsolateral side with 1 seta; urosomal segment 2 on each dorsolateral side with 2 spines or 1 spine and 2 setae; urosomal segment 3 naked.

Epimeral plate 1 poorly concave ventrally and with obtusely angular ventroposterior corner defined by 1 corner slender spine, posterior margin almost sinusoid, with several short marginal setae (fig. 8A); epimeral plate 2 poorly acute with obtuse ventroposterior corner defined by one corner spine-like seta, posterior margin with 3-4 short marginal setae; epimeral plate 3 poorly acute, with obtuse ventroposterior corner defined by 1 spine-like seta, posterior margin poorly inclined and provided with 5-6 short setae. Epimeral plates 2 and 3 with 3 subventral spines each (fig. 8A).

Antenna 1 almost reaching half of body-length (ratio: 40:81), main flagellum consisting of 21 articles. 

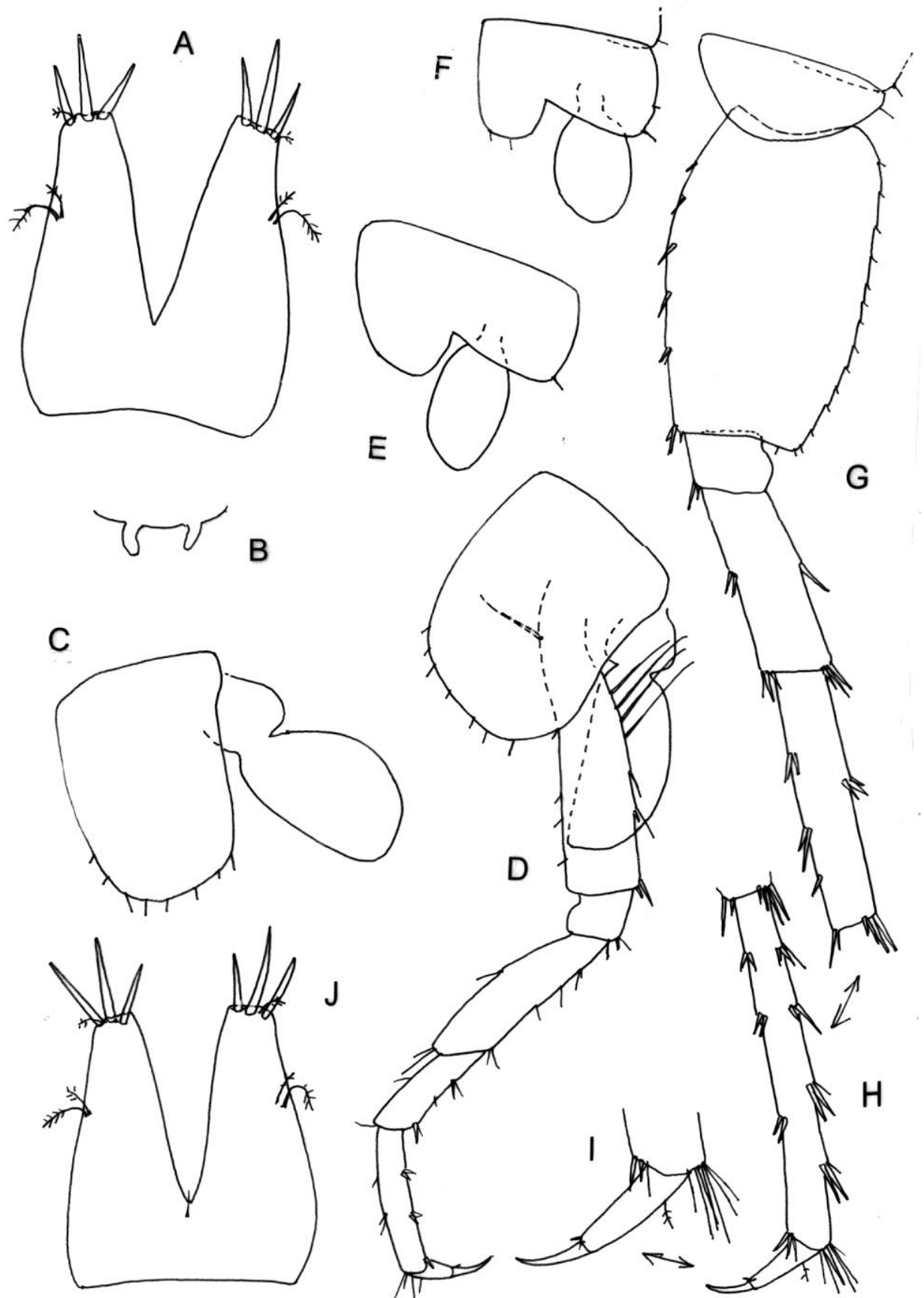

G
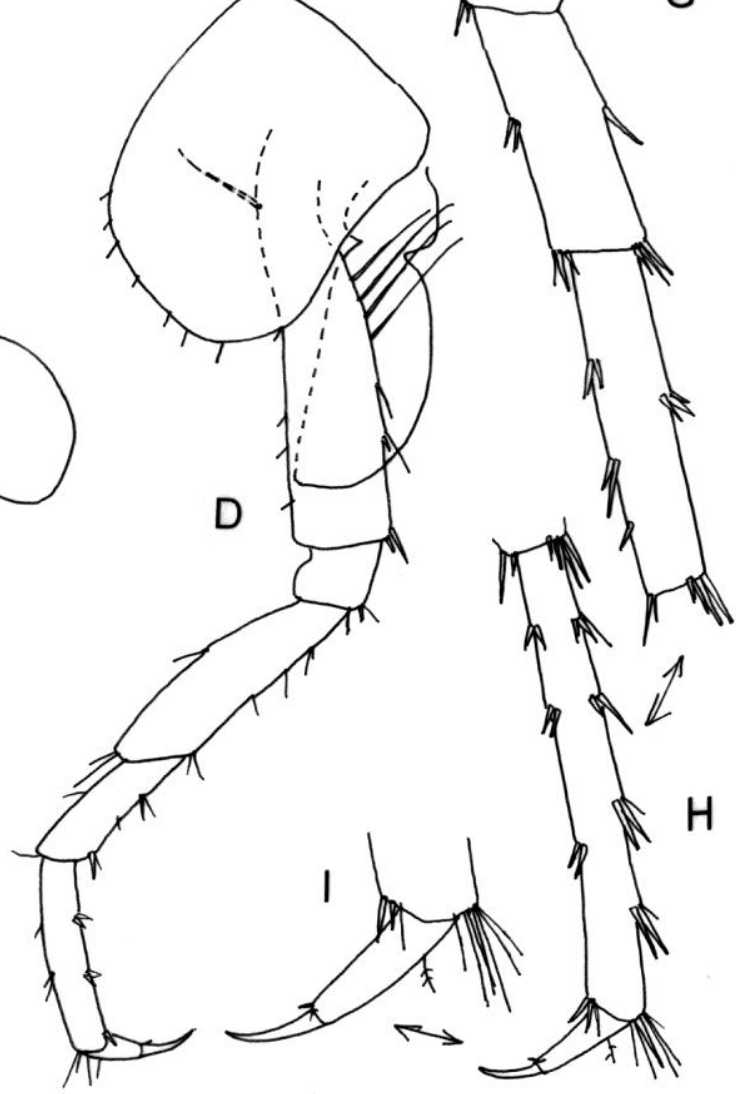

$\mathrm{H}$

Figure 6. Exniphargus tzanisi, gen. n. sp. n., Tzanis spilios, Crete Island, male $8.5 \mathrm{~mm}$ (holotype): $\mathrm{A}=$ telson; $\mathrm{B}=$ ventral sexual papillae.

Female $8.2 \mathrm{~mm}$ (paratype): $\mathrm{C}=\operatorname{coxa} 3 ; \mathrm{D}=\operatorname{pereopod} 4 ; \mathrm{E}=\operatorname{coxa} 5 ; \mathrm{F}=\operatorname{coxa} 6$; $\mathrm{G}-$ $\mathrm{H}-\mathrm{I}=$ pereopod $7 ; \mathrm{J}=$ telson. 
Antenna 2 like that in male, flagellum consisting of 8 articles. Mouthparts like these in male. Maxilla 1 like that in male.

Maxilliped: inner plate with 3 distal spines accompanied by several strong distal and distolateral spine-like setae (fig. 7A); right palpus article 4 with 3 distal nails accompanied by 4 short setae sitting below the nails, at outer margin with one median seta (fig. 7B). Left palpus article 4 with 3 distal nails accompanied by 3 distoventral short setae, at outer margin with 1 median strong seta (fig. 7C).

Coxa 1 broader than long (ratio: 43:33), with subrounded ventroanterior corner and bearing 4 marginal setae (fig. 7D). Coxa 2 as long as broad, having on subrounded ventral margin 9 short setae (fig. 7F). Coxa 3 longer than broad (ratio: 62:44), at ventral margin with 8 short setae (fig. 6C); coxa 4 slightly longer than broad (ratio: 65:50), with 8 short marginal setae (fig. 6D). Coxa 5 broader than long (ratio: 62:38), with subrounded anterior margin (fig. 6E). Coxa 6 smaller than 5, broader than long (ratio: 47:30) (fig. 6F). Coxa 7 entire, broader than long (ratio: 51:24), with convex ventral margin (fig. 6G).

Gnathopods 1-2 rather similar to these in male. Gnathopod 1: article 2 along anterior and posterior margin with numerous long setae (fig. 7D); article 3 at posterior margin with one bunch of setae; article 5 shorter than propodus (ratio: 32:43), at anterior margin with distal bunch of setae (fig. 7D). Propodus trapezoid, slightly longer than broad (ratio: 65:60), along posterior margin with 5 transverse rows of setae (fig. 7E). Palm convex, inclined hardly over half of propodus-length, defined on outer face by one corner S-spine accompanied laterally by 3 slender L-spines and facial $5 \mathrm{M}$-setae (fig. 7E), on inner face by one subcorner R-spine. Dactylus reaching posterior margin of propodus, along outer margin with 6 strong median setae, along inner margin with over 12 short setae (fig. 7E).

Gnathopod 2: article 2 with naked proximoanterior margin, and with 6 shorter setae in distal margin, along posterior margin with long setae in proximal part and short setae in distal part; article 3 at posterior margin with one bunch of setae (fig. 7F); article 5 shorter than 6 (ratio: 38:52), at anterior margin with one distal seta. Propodus trapezoid, poorly longer than broad (ratio: 80:75), along posterior margin with 8 transverse groups of setae (fig. 7G); palm convex, inclined poorly over half of propodus-length, defined on outer face by one corner $\mathrm{S}$-spine accompanied by $2 \mathrm{~L}$-spines and 4 long facial M-setae (fig. 7F), on inner face by one subcorner R-spine. Dactylus reaching posterior margin of propodus, along outer margin with 5 median setae, along inner margin with nearly 11 short setae (fig. 7G).

Pereopods 3 and 4 similar to each other, scarcely setose. Pereopod 4: article 2 along anterior margin with 1 long proximal seta and several short setae in distal part, along posterior margin with several short setae and spines (fig. 6D). Articles 4-6 of different length (ratio: 47:30:39), baring very short setae and single spines; dactylus shorter than article 6 (ratio: 22:39), at inner margin with one short spine-like seta, on outer margin with one median plumose seta (fig. 6D), nail slightly shorter than peduncle (ratio: 10:13). 


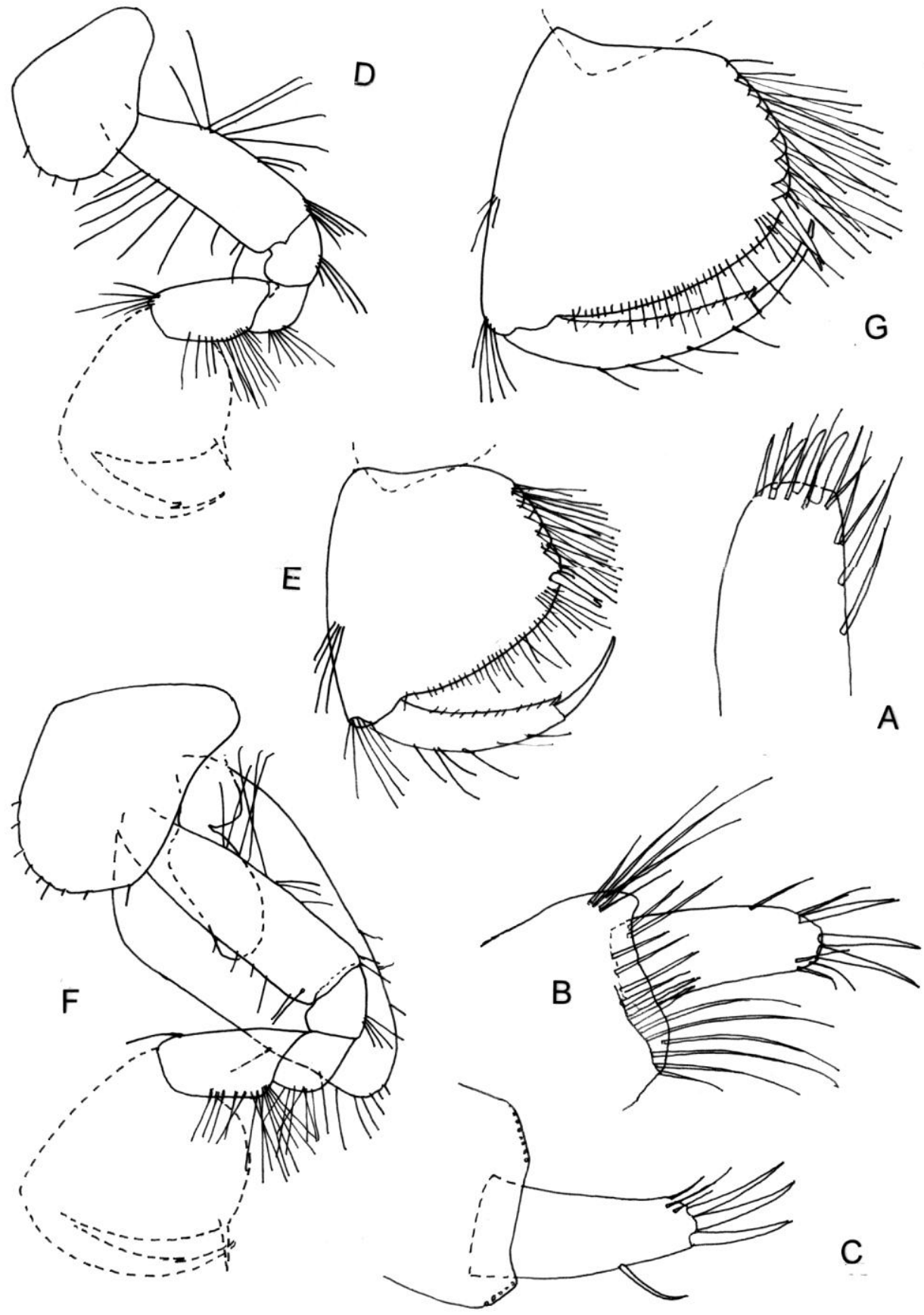

Figure 7. Exniphargus tzanisi, gen. n. sp. n., Tzanis spilios, Crete Island, female $8.2 \mathrm{~mm}$ (paratype): $\mathrm{A}=$ inner plate of maxilliped; $\mathrm{B}=$ right article 4 of maxilliped palpus; $\mathrm{C}=$ left article 4 of maxilliped palpus; $\mathrm{D}-\mathrm{E}=$ gnathopod 1 , outer face; F$\mathrm{G}=$ gnathopod 2 , outer face. 
Pereopods 5-7 similar to these in male. Pereopod 7: article 2 longer than broad (ratio: 87:54), along anterior convex margin with 6 groups of spine-like setae, along posterior convex margin with 15 short setae, ventroposterior lobe not fully developed (fig. 6G). Articles 4-6 of different length (ratio: 52:70:96), along both margins with bunches of short strong spines; article 2 slightly shorter than article 6 (ratio: 87:96) (fig. 6H). Dactylus shorter than article 6 (ratio: 30:96), at inner margin with one short slender spine and one short seta near basis of the nail, at outer margin with one median plumose seta (fig. 6 I); nail shorter than pedestal (ratio: 20:33).

Pleopods 1-3 with 2 retinacula each; peduncle of all pleopods naked.

Uropod 1: peduncle slightly longer than rami, with dorsoexternal row of strong spines, dorsointernal margin with distal spine only (fig. 8B). Rami equally long, outer ramus with several lateral and 4 distal short strong spines; 2 groups of 1-2 setae are attached at lateral margin; inner ramus with 2 lateral spines and 4 distal short spines (fig. 8B).

Uropod 2: peduncle with dorsodistal spines; rami of equal length: outer ramus hardly recurved, with one lateral and 5 distal short strong spines (fig. 8C); inner ramus with one lateral and 5 distal short spines.

Uropod 3: peduncle rather longer than broad (ratio: 38:22), with several distal spines (fig. 8D). Inner ramus short, consisting of one article, scale-like, shorter than peduncle and provided with one distal spine and lateral short seta (fig. 8D); outer ramus 2-articulated: first article at outer ramus with 3 bunches of spines not exceeding diameter of article itself; along inner margin are attached 5 bunches of short strong spines mixed with single plumose setae longer than spines. Second article much shorter than first one (ratio: 26:125), bearing one lateral and one distal bunch of short simple setae (fig. 8D).

Telson slightly longer than broad (ratio: 73:66), incised over $2 / 3$ of telson-length, rather gaping; lobes tapering distally and provided with 3 short spines (the longest spines not reaching $1 / 3$ of telson-length; a pair of short plumose setae is attached rather over middle of outer margin in each lobe (fig. $6 \mathrm{~J})$.

Coxal gills like these in male, not reaching ventral margin of corresponding article 2 of legs (figs. 6D, 7F). Oostegites appear on corresponding legs 2-5, very large, with marginal setae (fig. 7F).

VARIABILITY. Rather variable position of distal nails on palpus article 4 in maxilliped was observed; rami of uropod 1 and 2 are of equal length or almost unequal (inner ramus hardly longer).

The stable characters are the presence of 3 nails on maxilliped palpus, presence of numerous slender pectinate spines on outer plate of maxilla 1 .

HOLOTYPE: male, $8.5 \mathrm{~mm}$. Holotype and paratypes are deposited in KARAMAN`s Collection in Podgorica, Montenegro.

DERIVATIO NOMINIS. The name of the species "tzanisi" was nominated according to the name of the locality Tzanis on Crete Island. 


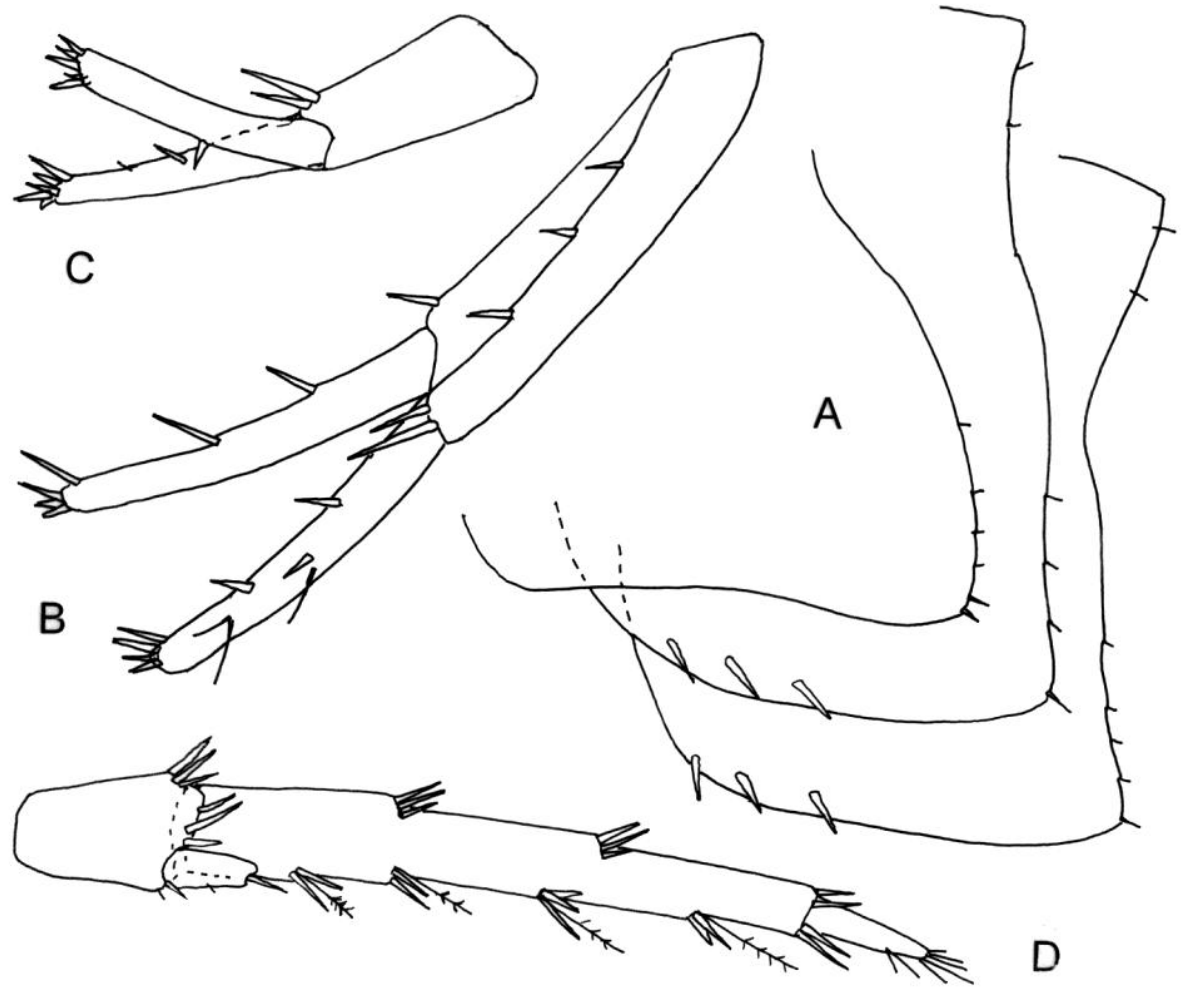

Figure 8. Exniphargus tzanisi, gen. n. sp. n., Tzanis spilios, Crete Island, female $8.2 \mathrm{~mm}$ (paratype): $\mathrm{A}=$ epimeral plates $1-3 ; \mathrm{B}=\operatorname{uropod} 1 ; \mathrm{C}=\operatorname{uropod} 2 ; \mathrm{D}=$ uropod 3 .

\section{REMARKS AND AFFINITIES.}

The new species, Exniphargus tzanisi differs from all known taxa of the family Niphagidae by presence of 3 distal nails (spines) of maxilliped palpus article 4.

On the other side, within genus Niphargus the most of taxa have one nail on maxilliped palpus article 4 (Niphargus cvijici S. Karaman 1950, etc.). Some species of this genus are provided with 2 nails of maxilliped palpus article 4 [Niphargus krameri Schellenberg, 1935 (loc. typ.: Pazin, Istra, Croatia], but all other taxonomic characters of $N$. krameri agree with diagnostic characters of genus Niphargus.

Genus Pontoniphargus has outer plate of maxilla 1 with 7 pectinate spines, and maxilliped palpus article 4 with distal setae (Pontoniphargus racovitzai Dancau, 1970).

The presence of elevated number of distal spines on maxilla 1 outer plate was observed in various species of genus Niphargus [8-9 spines with one lateral tooth each in Niphargus remyi S. Karaman, 1934) (G. Karaman, 2012b), but always with other taxonomic characters of genus Niphargus.

There are several other genera within family Niphargidae with numerous distal pectinate spines on maxilla 1 outer plate (genus Foroniphargus with 9-10 
pectinate spines and genus Niphargopsis with numerous (over 20) pectinate spines, genus Niphargobates with numerous multiserrate spines), but with different other taxonomical characters.

Among them, genus Niphargopsis seems to be more close to Exniphargus, but differs from Exniphargus, except maxilliped palpus, also by long lobes of maxilliped, very small inner plate of maxilla 1 bearing only one distal seta, kochianus-type gnathopods, much higher number of pectinate spines on maxilla 1 outer plate, etc., what eliminate the possibility to identify of taxon tzanius to the genus Niphargopsis.

By this way, the species tzanius differs from all other known genera by combination of taxonomic characters (maxilla 1, maxilliped, accessory flagellum, uropod 3, maxilla 2, etc.) and we created a new genus Exniphargus, gen. nov. (diagnosis see above).

The species Niphargobates orophobata Sket, 1981 (Type species of genus Niphargobates Sket, 1981), described from the subterranean waters of Slovenia, is with following diagnosis:

\section{DIAGNOSIS OF GENUS Niphargobates Sket, 1981}

Accessory flagellum is consisting of one article. Mandible Nipharguslike but with high number of rakers, palpus 3-articulate but shortened, palpus article 3 is not subfalciform, bearing distal E-setae only. Maxilla 1 outer plate dilated, with numerous pectinate spines and reduced very small palpus consisting of one article bearing one small distal seta. Inner plate of maxilla 2 is much larger than outer plate. Maxilliped: outer plate is remarkably longer than inner plate, palpus article 4 short, with distal nail. Uropods 1-2 slender, biramous,

uropod 3 very short and stout, inner ramus consisting of one article, scale-like; outer ramus consisting of one article, short, spinose distally and with some lateral strong spines, no plumose setae. Telson very short and broad, broadly excavated distally less than half of telson-length.

1981

TYPUS GENERIS (Type species): Niphargobates orophobata Sket,

TAXA: Type-species known only.

DISTRIBUTION: Planinska Jama Cave near Postojna, Slovenia.

The species Niphargobates lefkodemonaki Sket, 1990, differs remarkably from the type species of this genus (Niphargobates orophobata Sket, 1981\}, by elongated uropod 3 having 2-articulated outer ramus, Niphargus-like; accessory flagellum 2-articulated; telson normal, Niphargus-like; normal distal subfalciform palpus article 3 of mandible, bearing at least D and E-setae. Based on these differences we removed the taxon $N$. lefkodemonaki to the new genus Niphargobatoides, gen. nov. as a type species.

DIAGNOSIS OF THE GENUS Niphargobatoides:

Eyes absent, head with short rostrum, accessory flagellum 2-articulated; labium without inner lobes; mandible Niphargus-like, with triturative molar and well developed 3-articulate palpus having A, B, D and E-setae. Maxilla 1 inner plate well developed, with distal setae; outer plate dilated, bearing numerous 
recurved serrate spines, palpus shortened, consisting of one article, with distal setae. Maxilla 2 inner plate much larger than outer plate, both lobes with marginal setae. Maxilliped inner plate remarkably shorter than outer plate, palpus article 4 (dactylus) short, with distal nail. Coxae moderately large, coxa 5 almost as long as coxa 4. Gnathopods and pereopods 3-7 like these in Niphargus. Pleopods 1-3 well developed. Uropods 1 and 2 biramous, rami well developed, with spines, Niphargus-like. Uropod 3 Niphargus-like, with inner ramus short, consisting of one article, scale-like, outer ramus 2 -articulate, second article short. Telson deeply incised, bilobed, with spines.

(Sket, 1990)

TYPUS GENERIS (Type species): Niphargobatoides lefkodemonaki

TAXA: Type species known only.

DISTRIBUTION: Crete Island, Greece.

\section{Key to the genera of the family Niphargidae}

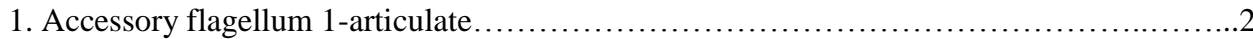

---Accessory flagellum 2-articulate.

NIPHARGOBATES Sket, 1981

2. Maxilla 1 palpus consisting of one article

---Maxilla 1 palpus consisting of 2 articles

3. Uropod 3 outer ramus consisting of one short article..............CARINURELLA Sket, 1971

---Uropod 3 outer ramus consisting of 2 articles.

4. Mandible palpus partially reduced, bearing distal E-setae only. Body slender, elongated........................................ICRONIPHARGUS Schellenberg, 1934

---Mandible palpus well developed, subfalciform, with at least D and E-setae. Body adapted to the rolling in the ball. KARAMANIELLA Sket, 1962

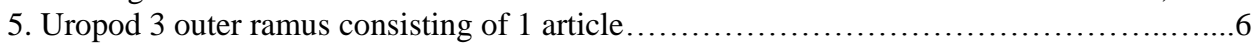

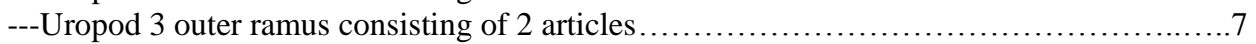

6. Maxilla 1 palpus consisting of 1 shortened article...........NIPHARGOBATOIDES gen. nov.

---Maxilla 1 palpus well developed, consisting of 2 articles.

HAPLOGINGLYMUS Mateus \& Mateus 1958

7. Uropod 3 inner ramus well developed, long, exceeding half of outer ramus PONTONIPHARGUS Dancau, 1970

---Uropod 3 inner ramus short, more or less scale-like, much shorter than first article of outer ramus.

8. Maxilliped palpus article 4 with 3 distal nails (maxilla 1 outer plate with numerous pectinate slender spines). EXNIPHARGUS gen. nov.

--- Maxilliped palpus article 4 with one, exceptionally 2 distal nails .......................

9. Maxilla 1 outer plate with over 20 pectinate spines........ NIPHARGOPSIS Chevreux, 1922

--- Maxilla 1 outer plate with 7-8, rarely up to 10 simple or pectinate spines..................10

10. Mandible palpus article 3 partially reduced, bearing distal E-setae only...

.NIPHARGELLUS Schellenberg, 1938

---Mandible palpus article 3 well developed, subfalciform, with at least D and E setae........ 11 11. Maxilliped inner and outer plate short and broad; maxilla 2 both plates are short and broad; maxilla 1 inner plate very strong, broader than palpus, outer plate with 9-10 pectinate spines, palpus short, not exceeding basis of outer plate spines

FORONIPHARGUS G. Karaman, 1985

---Maxilliped inner and outer plate slender; maxilla 2 both plates are slender; maxilla 1 inner plate is slender, narrowed distally, outer plate with 7-9 simple to pectinate spines, palpus longer, exceeding basis of outer plate spines. NIPHARGUS Schiǒdte, 1849 


\section{CONCLUSION}

Based on the morphological characteristics of the members of the family Niphargidae, we tried to recognize the distinct genera within the family Niphargidae, taking in consideration the most stable taxonomic characters, which are not variable within members of each genus. By this way each genus can be recognize based on certain stable morphological characteristics. This is not the phylogenetic approach, because we tried to facilitate the recognition of single species and genera based on external morphological data. We can suppose that the further genetic and molecular investigations of these taxa will have maybe some different ideas about the division of taxa within the Niphargidae family, but we hope that our work will facilitate further investigations of this problem.

The genus Niphargus (sensu auctorum), having polyphyletic origin, probably is composed of more different groups known recently as different subgenera or Complex of species, needs further detailed morphological, genetic and other studies to understand the taxonomy of this genus.

\section{ACKNOWLEDGEMENTS}

I am thankful to the Academician Prof. Dr. Boris Sket from Ljubljana (Slovenia) for the loan of material used in this study. This work was realized thanks to the support of the Montenegrin Academy of Sciences and Arts.

\section{REFERENCES}

Chevreux, E. 1922. Sur un nouveau genre d amphipodes de la faune francaise. Bulletin du Muséum National d'Histoire Naturelle, Paris, 7: 487-488.

Dancau, D. 1970. Sur un nouvel amphipode souterrain de Roumanie, Pontoniphargus racovitzai, n. g., n. sp. --Livre de centenaire Emile Racovitza 1868-1968, Acad. Rep. Soc. Roumanie, pp. 275-285.

Karaman, G. 1969.. XXVII. Beitrag zur Kenntnis der Amphipoden. Arten der Genera Echinogammarus Stebb. und Chaetogammarus Mart. an der jugoslawischer Adriaküste.- Glasnik Republičkog zavoda za zaštitu prirode i Prirodnjačke zbirke u Titogradu, 2: 59-84.

Karaman, G. 1974. 59. Contribution to the Knowledge of the Amphipoda. Revision of the genus Stygobromus Cope 1872 (Fam. Gammaridae) from North America. - Glasnik Republičkog. zavoda za zaštitu prirodePrirodnjačkog muzeja Titograd, 7: 97-125.

Karaman, G. 1984. Contribution to the Knowledge of the Amphipoda 148. Niphargus krameri Schell. and N. spinulifemur S. Kar. in southern Europe.

- Glasnik Prirodnjačkog muzeja, Beograd, ser. B, 39: 85-104.

Karaman, G. 1985. Foroniphargus pori, new genus and species of family Niphargidae (Contribution to the Knowledge of the Amphipoda 152) Poljoprivreda i šumarstvo, Titograd, 31 (4): 51-66.

Karaman, G. 1993. Crustacea Amphipoda di acqua dolce. - Fauna d`Italia, vol. XXXI: 1-337, Edizione Calderini Bologna, Italia.

Karaman, G. 2012a Further investigations of the subterranean genus Niphargus Schiödte, 1849 (fam. Niphargidae) in Serbia. (Contribution to the 
Knowledge of the Amphipoda 264).- Agriculture and Forestry, Podgorica, 58 (2): 45-64.

Karaman, G. 2012b. Investigations on two subterranean species of the family Niphargidae (Gammaridea) from Serbia, Niphargus remyi S. Kar. 1934 and $N$. euserbicus, sp. n. (Contribution to the Knowledge of the Amphipoda 266).- Agriculture \& Forestry, 58 (3): 63-95, Podgorica.

Karaman, S. 1934. VI. Beitrag zur Kenntnis jugoslawischer Süsswasseramphipoden.- Zoologischer Anzeiger, Leipzig, 107 (11/12): 325-333, figs. 1-4.

Karaman, S. 1950. Dve nove vrste podzemnih amfipoda Popova polja u Hercegovini. (= Zwei neue Arten unterirdischen Amphipoden von Popovo Polje in der Hercegovina).- Srpska Akademija Nauka, Posebna Izdanja knj. 158, Odelenje Prirodno-matematičkih nauka, Beograd, 2: 101-118, figs. 124.

Mateus, A. \& Mateus, E. 1958. Un nouveau genre et une nouvelle espece d`Amphipode troglobie du Portugal. - Publicaçoes do Instituto de Zoologia "Dr. Augusto Nobre", Faculdade de Ciencias do Porto, Coimbra, 59: 1-15, figs. 1-11.

Schellenberg, A. 1934. Eine neue Amphipoden-Gattung aus einer belgischen Höhle nebst Bemerkungen über die Gattung Crangonyx. - Zoologischer Anzeiger, 106 (9): 215-218.

Schellenberg, A. 1935. Schlüssel der Amphipodengattung Niphargus mit Fundortangaben und mehreren neuen Formen.- Zoologischer Anzeiger, 111 (7-8): 204-211.

Schellenberg, A. 1938. Niphargellus, eine neue subterrane Amphipodengattung an der Ost- und Westgrenze des Reiches.- Zoologischer Anzeiger, 122 (910): $245-248$.

Schiödte, J.C. 1849. Bidrag til den underjordiske Fauna. -Det kongelige danske Videnskabernes Selskabs Skrifter. Femte Raekke. Naturvidenskabelig og mathematisk Afdeling. Andet Bind. Kjobenhavn, 2(5): 1-39.

Sket, B. 1962. Karamaniella pupetta, n. g., n. sp., ein neuer Amphipode aus Slovenien. - Izdanija, Zavod za Ribarstvo Makedonije, 3 (2): 27-32 (1960), Skopje.

Sket, B. 1971. Vier neue aberrante Niphargus-Arten (Amphipoda, Gammaridae) und einige Bemerkungen zur Taxonomie der Niphargus-ähnlichen Gruppen. - Razprave, Slovenska Akademija Znanosti in Umetnosti, Ljubljana, 14 (1): 1-25.

Sket, B. 1981. Niphargobates orophobata n. g., n. sp. (Amphipoda, Gammaridae, s. 1.) from cave waters in Slovenia (NW Yugoslavia).- Biološki Vestnik, Ljubljana, 29 (1): 105-118.

Sket, B. 1990. Is Niphargobates lefkodemonaki sp. n. (Crustacea: Amphipoda) from Kriti ( Greece) a Zoogeographical Enigma? - Zoologische Jahrbücher, Abteilung für Systematik, 117: 1-10. 